\title{
REPRODUCTIVE CHARACTERISTICS OF INDONESIA MAHSEER (Tor tambroides, Bleeker, 1854), IN TWO DIFFERENT RIVERS IN WESTERN SUMATERA
}

\author{
Arif Wibowo and Siswanta Kaban \\ Research Institute for Inland Fisheries, Mariana \\ Received February 05-2014; Received in revised form October 29-2014; Accepted October 31-2014 \\ Email: wibarf@yahoo.com
}

\begin{abstract}
The reproductive characteristics of mahseer, Tor. tambroides, were studied in Manna River and Batang Tarusan River, which are located on each side of Western Sumatera River. The reproductive period of T. tambroides is largely consistent with that described for the species in other areas, however monthly variations in the extent and timing of peak spawning are recorded. The analysis of the sex ratio indicates an increase in the percentage of females with size, more marked in largest sizes. Seasonal patterns in the occurrences of spawning showed that the spawning season in Manna River lasted was similar with that in Batang Tarusan River, although a second prominent increase of GSI was observed in April and September in Manna River, meanwhile the GSI of Batang Tarusan River fish were below 2 without an apparent variation. L50s of Manna River and Batang Tarusan River mahseer were estimated as $24.5 \mathrm{~cm}$ and $20.66 \mathrm{~cm}$, respectively, indicating a high variability in size at first maturity of the mahseer population. Our study provides some important information on the reproductive biology of $T$. tambroides that will be helpful in similar studies and contributed to fisheries management of this species.
\end{abstract}

\section{KEYWORDS: Mahseer, reproductive characteristics, manna river, Batang Tarusan River}

\section{INTRODUCTION}

The estimation of fish basic life history characteristics, such as breeding season, age and size at maturity and fecundity, is fundamental to being able to make predictive generalizations on the responses of different species to environmental modification, understanding the adaptive responses of species to exploitation, guiding fisheries management, developing appropriate culture conditions, fuelling general ecological studies at the community or ecosystem level and/or designing broad reproductive strategies in fishes (e.g. Winemiller \& Rose, 1992).

Tor tambroides is in the Cyprinidae family typically inhabited waterfalls and has a long large flat torso with a long mental lobe and small head, green brown colours, large scales and $15-20 \mathrm{~cm}$ in body. Tor tambroides is sexually mature when mall, silvery with yellow, orange, pink or pale red fins (Polar et al., 2007). Some biological studies have been conducted on Tor tambroides for developing effective management measures due to its importance in the fishery. Esa et al. (2008) observed its genetic variation in wild population. Haryono \& Subagja (2008) reported its status and structure of population, habitat types, and preferences. Haryono (2006) studied its sexual maturity, fecundity, sexual dimorphism, sex ratio, food habits, parasites and disease.
However Information regarding changes in fish reproduction in response to changes in population dynamic has been poorly studied. It may be advantageous in some situations for females to suppress present reproduction in order to increase investment in future reproduction and lifetime reproductive success. The purpose of this study is to examine the reproductive biology performance of mahseer from two different rivers in Western Sumatera in response to changes in their population dynamic and social condition.

\section{MATERIALS AND METHODS \\ Sample description and collection locations}

Fish populations were sampled by a combination of cast net, seine-netting and hook at monthly intervals during the period of February to October 2012 from 5 sampling locations in Manna River, Bengkulu Province (Fig. 1) and during February to July 2012 from 3 sampling locations in Batang Tarusan River, West Sumatera Province (Fig. 2).

There were 340 samples from Manna River and 273 fish samples from Batang Tarusan River. We retained fish for laboratory examination after formalin solution $10 \%$ for 7 days, rinsed by flowing water and finally kept in $70 \%$ ethanol solution just before being measured in the laboratory. 


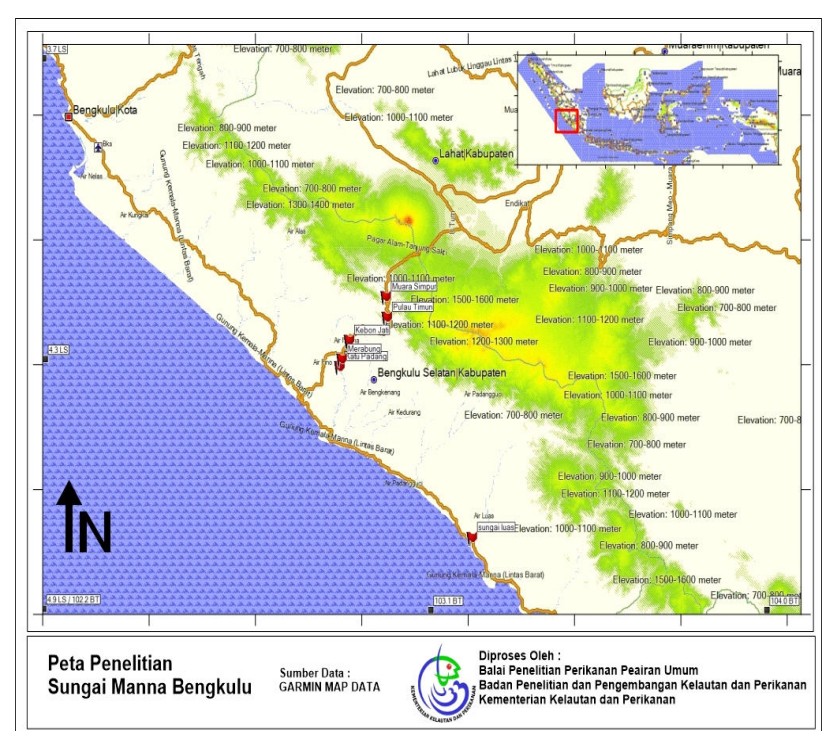

Figure 1. Location of the study sites in the Manna River drainage. Inset shows the location of 5 sampling sites in Manna River.

\section{Laboratory examination}

We measured the standard length (SL) and total length (TL) of collected mahseer to the nearest $1 \mathrm{~mm}$, weighed the body (to nearest $0.01 \mathrm{~g}$ ). The gonad was then removed, weighed and the gonadosomatic index (GSI) estimated. The sex of each individual was identified and the gonads were assigned a developmental stage based upon morphology and macroscopic examination. Ovaries and testes were allocated a developmental stage according to the criteria modified Cassie (Effendi, 1979). Gonads from both sexes were subsequently preserved and stored in $10 \%$ formalin.

The ovaries of each fish were examined macroscopically; their length and width were measured to the nearest $0.1 \mathrm{~mm}$. An ovarian subsample (about one third of the gonad) was removed and, weighed. We estimated total fecundity by scaling the number of eggs counted by the appropriate ratio of subsample to total ovarian weight. We also estimated mean egg diameter from a randomly selected sample using a calibrated ocular micrometer.

Histological preparations were made from 8 testes and ovaries representing each stage of development to check the accuracy of macroscopic staging and to better discriminate between mature and immature fish. Histological preparations were also made if a fish's sex or developmental stage was uncertain. To prepare

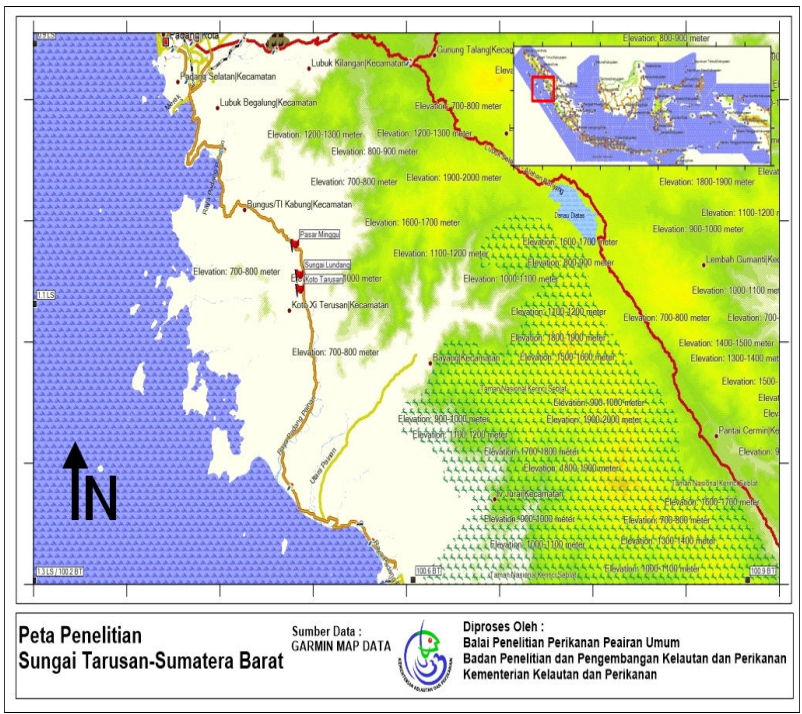

Figure 2. Location of the study sites in the Batang Tarusan River drainage. Inset shows the location of the 3 sampling sites in Batang Tarusan River drainage.

a gonad for histological examination, a small sample $(<0.5 \mathrm{~cm}$ thick) was taken from the central portion of the preserved left gonad, embedded in paraffin, sectioned to $6 \mu \mathrm{m}$ thickness, stained with Mayer's haematoxylin and eosinY, and mounted on a microscope slide (Hinton, 1990).

\section{Statistical analyses}

All lengths reported here are standard lengths. Sex ratio, expressed as female:male, was analyzed on a monthly by $1 \mathrm{~cm}$ length class basis. Deviations from 1:1 null hypothesis were statistically tested by chisquared test. Numbers of months of individuals were selected in each and their standard body length (SL), total body weight (TW) and gonad weight (GW) was measured to the nearest $0.1 \mathrm{~cm}, 0.01$ and $0.001 \mathrm{~g}$, respectively. The gonadosomatic index (GSI) was calculated as $\mathrm{GSI}=100 \mathrm{GW} / \mathrm{SW}$, where $\mathrm{SW}$ is the somatic body weight (TW " GW).

Length at first maturity $(L 50)$ was defined as the standard length which $50 \%$ of females were mature (at none spawning, spawning or spent states), and estimated for females collected over the spawning season. The following logistic equation (Crabtree et al., 1997) was fitted to the percentage of mature females $(P)$ by nonlinear regression: $P=100 /(1+$ $\exp (" a(S L$ " $b)))$, where $a$ and $b$ are the constants. In terms of this equation, constant $b$ represents the SL at the inflection point equivalent to the estimate of L50. 


\section{RESULTS AND DISCUSSION}

\section{Results}

Sex ratio

Sex ratios were significantly different from the expected 1:1 ratio (Table 1). Monthly, a significant dominance of males over the period of May -
September in Manna River and March - April and June - July in Batang Tarusan River was observed, whereas female were more abundant in Februar in both location. Sex ratio by size class (all month pooled) shows a dominance of females in the largest sizes, from 30 $\mathrm{cm}$ on in Manna River (Fig. 3) and there was not a dominance of female's pattern in Batang Tarusan River (Fig. 4).

Table. 1. Monthly sex ratios (F/M) at two different river of $T$. tambroides during period 2012, $\mathrm{p}$ chi-squared and degrees of freedom (in brackets) are also presented.

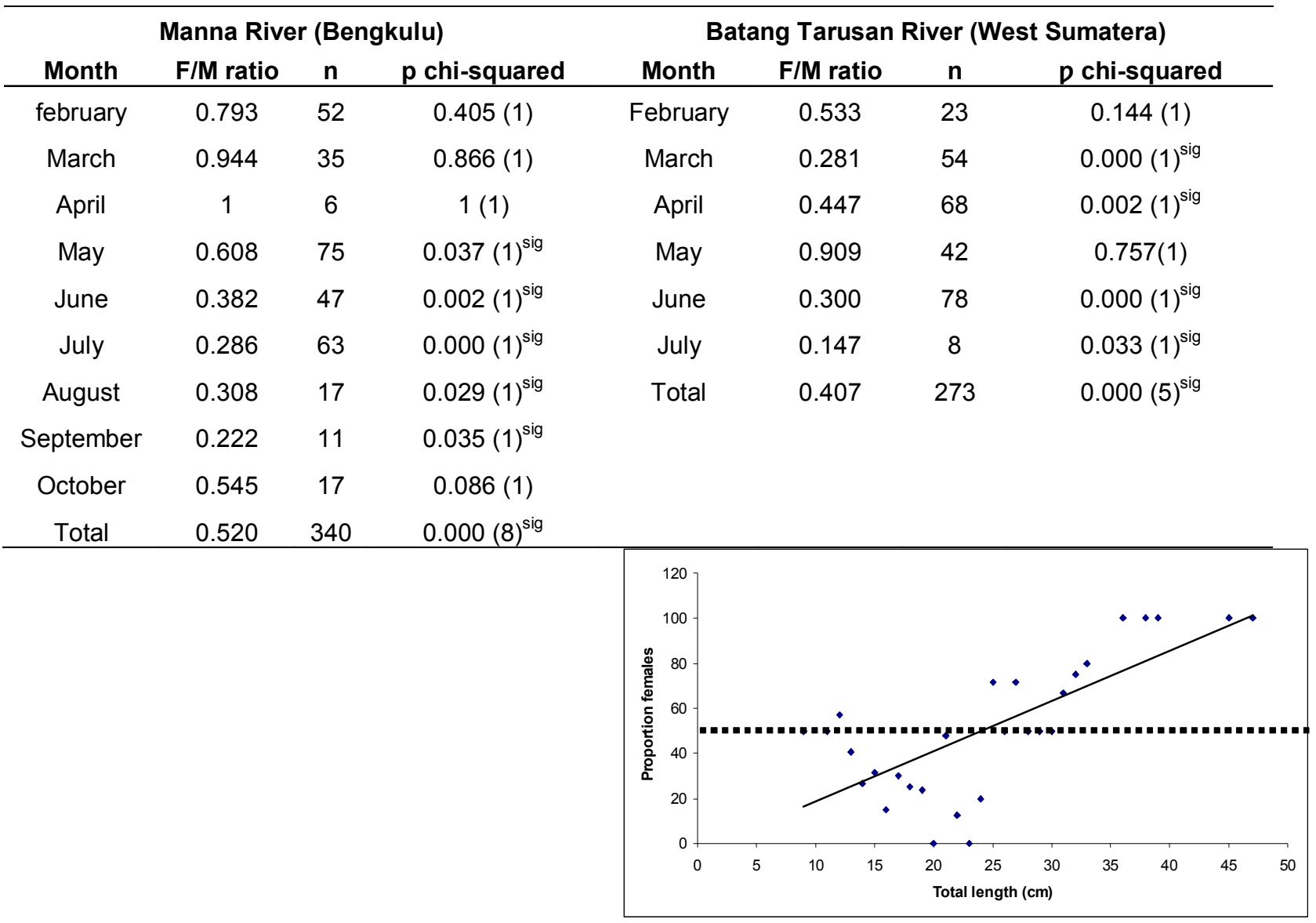

Figure 3. Percentage of females of T. tambroides by length class for the whole study period (2012) in Manna River

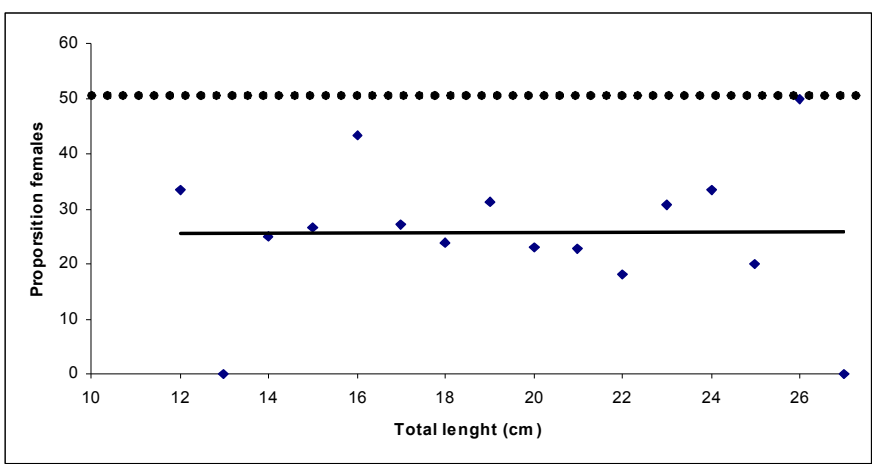

Figure 4. Percentage of females of $T$. tambroides by length class for the whole study period (2012) in Batang Tarusan River. 


\section{Gonad maturation cycle}

T. tambroides has an asynchronous ovary containing oocytes at various stages of development, Fig. 5. Ovarian maturity was classified into the following four stages based on the most advanced oocytes contained in the ovary. The immature phase (Stage I) includes oocytes in a perinucleolus or yolk vesicle-stage oocytes. The developing phase (Stage II) includes oocytes in a primary to tertiary yolk stage. The coexistence of postovulatory follicles at different yolked stages was observed in the developing phase.
The mature phase (Stage III) included oocytes in a migratory to maturity stage. Maturing: ovaries much larger, occupying a significant part of the abdominal cavity. They are filled with white or yellowish oocytes of different sizes. In the Ripe phase (Stage IV), Ripe: aspect almost identical to stage 3 , but the oocytes are partially ovulated (free in the ovarian cavity $=$ ovules) and can be expelled with a gentle pressure on the fish flanks. The ovary reaches its maximal development. This is an ephemeral stage just before the actual spawning event.
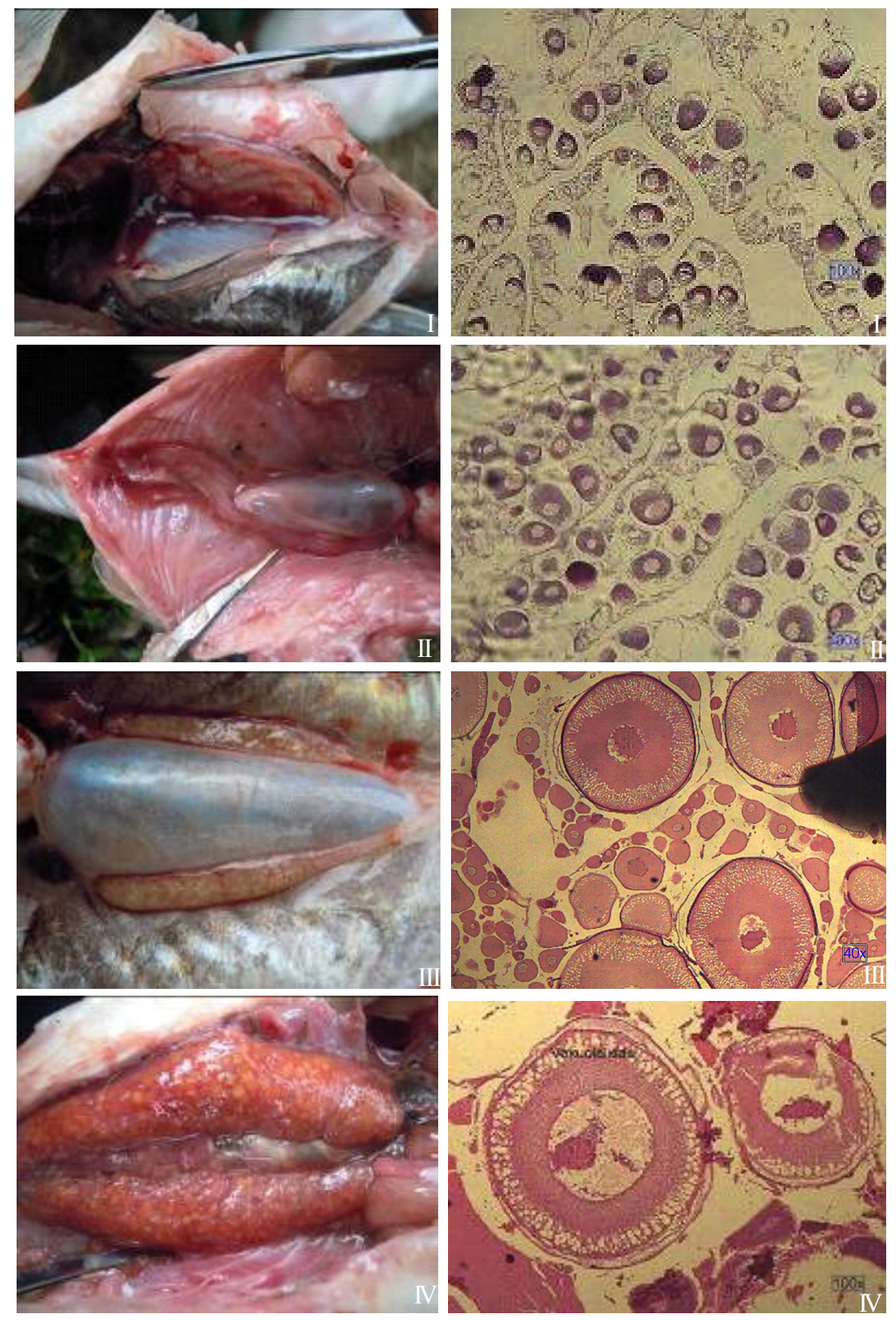

Figure 5. Morphology and histological maturation of the oocytes in Tor tambroides. 

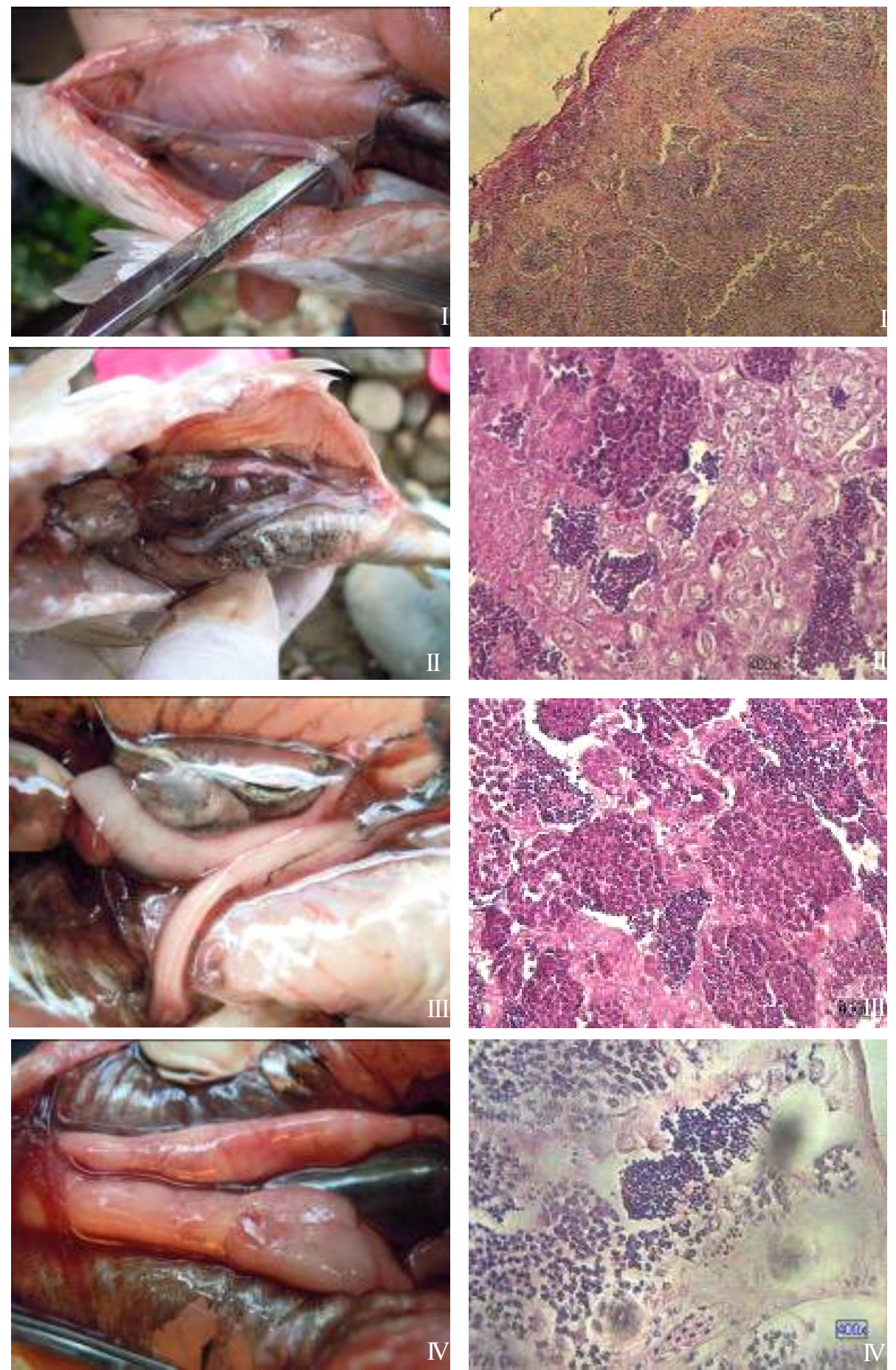

Figure 6. Morphology and testicular maturation stages in Tor tambroides.

As for females, the male's testicular stages are referred to by Arabic numbers, Fig. 6 . Stage I testes are characterized by the presence of spermatogonia nests embedded in abundant connective tissue. The developing phases (Stage II) are characterized by numerous well organized cysts with different spermatogenetic stages. Stage III males are characterized by whitish to pinkish, relatively large and turgescent testes of triangular or circular section, depending on the species. However, semen is never present within the sperm duct and even when squeezed vigorously, nothing comes out. Stage IV males are characterized by a larger, fuller, welldeveloped testes when compared to previous stages. A slight pressure of the testes surface makes the semen flow out of the sperm duct, which is definite indication of the stage IV testes. 


\section{Fecundity and egg size}

The absolute fecundity is amount of 2058 eggs in Manna River. Egg size was homogeneous within female, with variation around 0.015 . The mean absolute egg size is amount of $0.703 \pm 0.123 \mu \mathrm{m}$ in the Manna River, however we found no mature female in Batang Tarusan River.

\section{Gonadosomatic index}

For both sexes from Manna River, two large increases in mean GSI were observed: a first increase between March and April and a second increase between August and September (Fig. 7). On the other hand, mean GSI values of Batang Tarusan River samples showed only one apparent peak in June for both sexes. Furthermore, these values were $<2$ during the February-July period without a dramatic variation.

\section{Spawning Pattern}

In Manna River, spawning was observed for 8 months from February to October (Fig. 8). Spawning was present in six monthly samples collected between February and July in Batang Tarusan River. Hence, if we defined the spawning season as the period in which spawning were found, that in Manna River lasted similar with that in Batang Tarusan River.
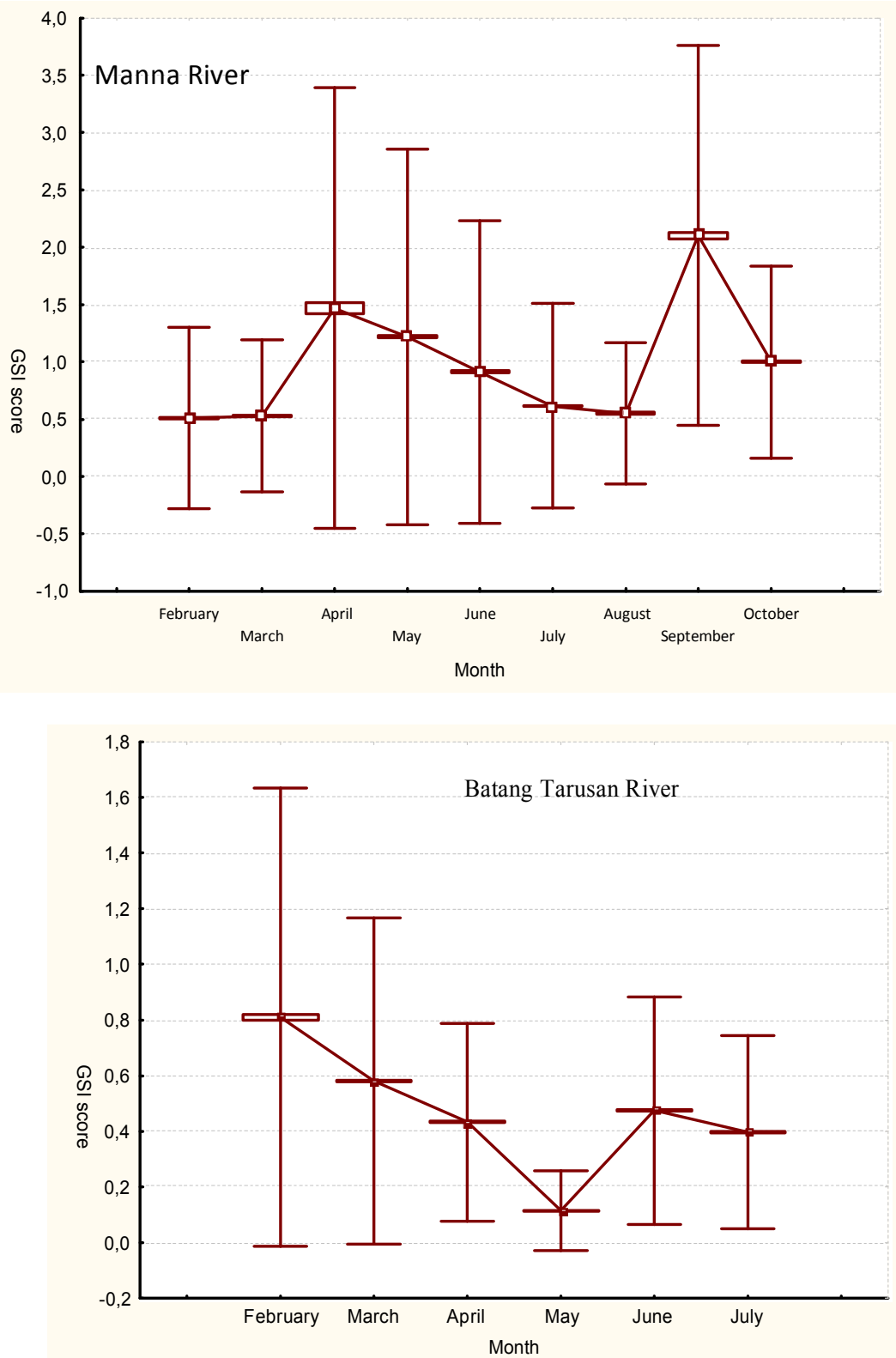

Figure 7. Seasonal changes in mean gonadosomatic of T. tambroides Manna River and Batang Tarusan River (vertical bars are standard deviations and box bars are standard error). 

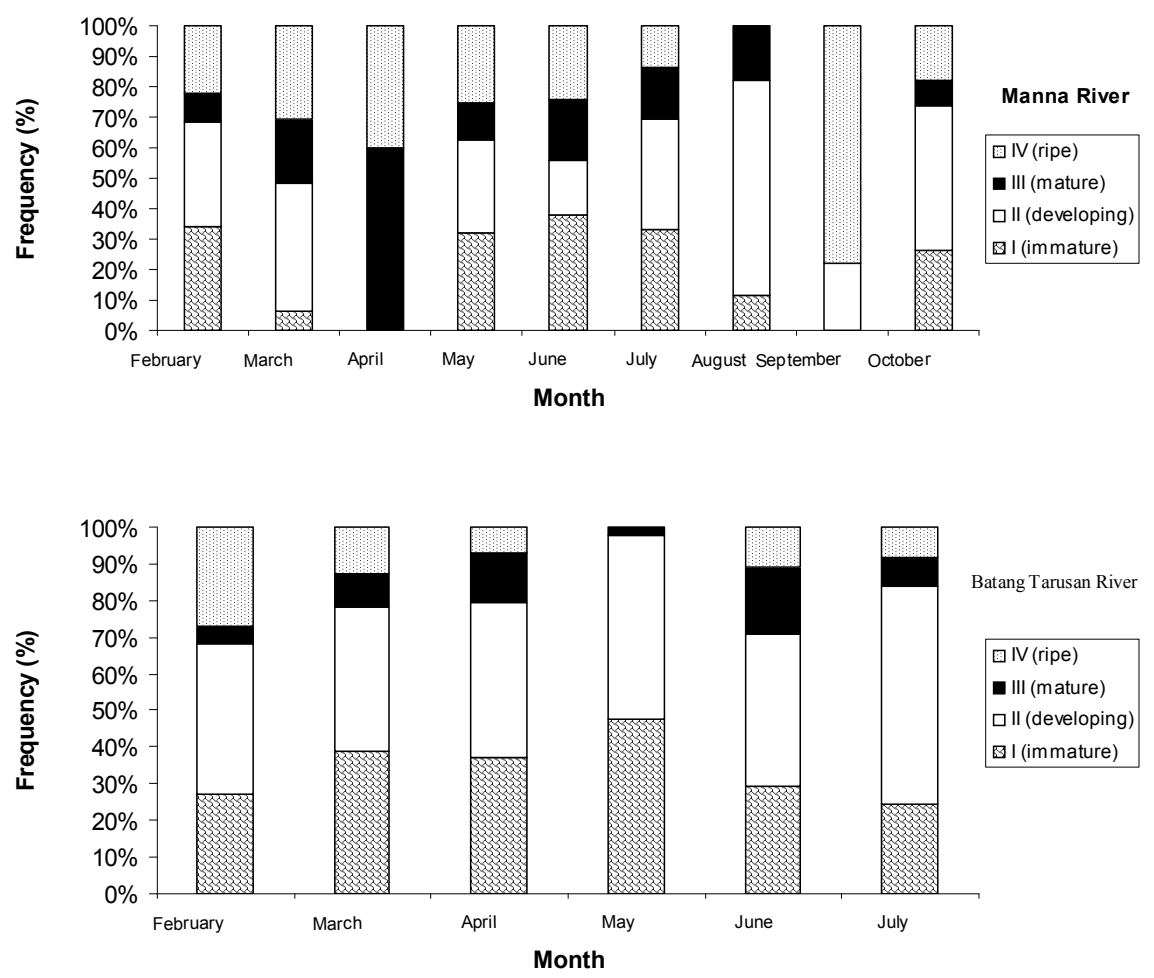

Figure 8. Monthly frequencies of spawning T. tambroides at various spawning states in Manna River and Batang Tarusan River.

\section{Length at first maturity}

For estimating $L 50$ of Manna River and Batang Tarusan River, a total of 116 and 91 females caught during 2012 were used. The logistic equations fitting to $P$ were calculated as $P=100 /(1+\exp$ ("2.78(SL "
24.5)) for Manna River sample and $P=100 /(1+$ $\exp ($ "2.88(SL " 20.66)) for Batang Tarusan River sample (Fig. 9). Based on these equations, SL at the inflection point equivalent to $L 50$ were estimated as $24.50 \mathrm{~cm}$ in Manna River and $20.66 \mathrm{~cm}$ in Batang Tarusan River.

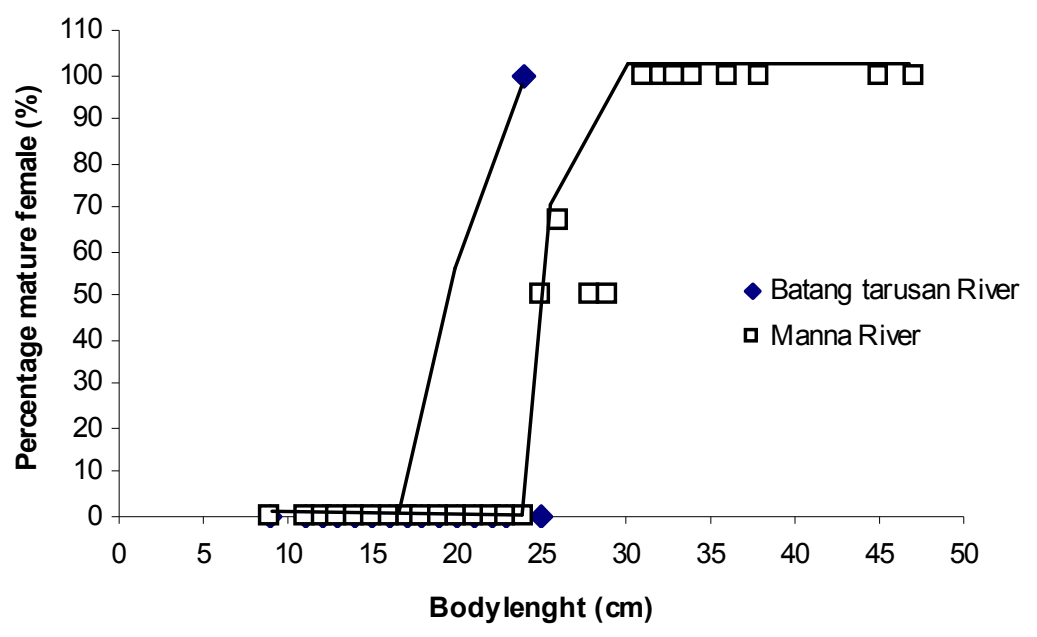

Figure 9. Maturity ogive in female T. tambroides in Manna River and Batang Tarusan River. 


\section{DISCUSSION}

The reproductive period of $T$. tambroides is largely consistent with that described for the species in other areas (Tan, 1980). However, monthly variations in the extent and timing of peak spawning are recorded and small differences are found in the timing of the peak spawning, which are probably related to differences in the environmental parameters.

The analysis of the sex ratio indicates an increase in the percentage of females with size, more marked in largest sizes. This size age-dependence of the sex ratio was also reported in other fish species by Lucio \& Uriarte (1990). The dominance of females in larger size may be caused by sex-related differences in growth rates (Parrish et al., 1986) and/or a natural mortality related to reproduction (Motos and Uriarte, 1991). We found most monthly sex ratios were not fulfilling the null hypothesis of a 1:1 ratio in both locations which is similar elsewhere as it congruent with Haryono (2006). According to Kiat (2004), the sex ratios of $T$. tambroides and other freshwater fish species are always changing depending on population and water quality. Thus information regarding the sex ratio above can change depending on the situation.

The absoult fecundity of $T$. tambroides in Manna River less than reported by Haryono (2006), this result can be understood because of different fish size observation. It is assumed that there is relationship between female length and the number and size of eggs produced. Seasonal patterns in the occurrences of spawning show that the spawning season in Manna River lasted similar with that in Batang Tarusan River. The monthly trends in GSI agree with these results, although a second prominent increase of GSI was observed in April and September in Manna River. In Batang Tarusan River, GSI were below 2 without an apparent variation. In general, the reproductive cycle of fish is affected by abiotic (e.g., water temperature and day length) and biotic (e.g., prey abundance) factors (Wootton, 1998).

L50s of Manna River and Batang Tarusan River mahseer were estimated as $24.50 \mathrm{~cm}$ and $20.66 \mathrm{~cm}$, respectively, indicating a high variability in size at first maturity of the mahseer population. In several reports, influences of changes in growth rates on size and age maturity through changes in adult or juvenile mortality have been examined (Stearns \& Crandall, 1984; Stearns and Koella, 1986). In fact, length and age at maturity seem to be dependent on growth rate in many fishes including the Nile tilapia Oreochromis niloticus (Duponchelle and Panfili, 1998) and the
American plaice Hippoglossoides platessoides (Morgan \& Colbourne, 1999).

The earlier maturity of females observed in Batang Tarusan River could lead to an increased adult life span, perhaps compensating for low absolute fecundity at each spawning. These populations with comparatively smaller females would always produce fewer offspring in absolute terms, because female fecundity increases with body size (Jonsson \& Jonsson, 1993). Our study provides some important information on the reproductive biology of $T$. tambroides that would be helpful in similar studies and contributed to fisheries management of this species.

\section{ACKNOWLEDGMENTS}

We would like to thank the support of Research Institute for Inland Fisheries staff for their help in the field work. Also, we thank the Research Institute for Inland Fisheries through DIPA 2012 for funding this work.

\section{REFERENCES}

Crabtree, R.E., D. Snodgrass \& C.W. Harnden. 1997. Maturation and reproductive seasonality in bonefish, Albula vulpes, from the waters of the Florida Keys. Fish. Bull. U.S, 95: 456-465.

Duponchelle, F \& J. Panfili. 1998. Variations in age and size at maturityof female Nile tilapia, Oreochromis niloticus, populations from man-made lakes of Code d'Ivoire. Environ. Biol. Fish, 52: 453465.

Effendie, M.I. 1979. Fisheries Biology Methods. Yayasan Dewi Sri. Bogor. (In Bahasa Indonesia).

Esa, Y.B., S.S. Siraj, S.K. Daud, K.A.A. Rahim, J.R.R. Japning and S.G. Tan. 2008. Mitochondrial DNA Diversity of Tor tambroides Valenciennes (Cyprinidae) from Five Natural Populations in Malaysia. Zoological Studies, 47(3): 360-367.

Haryono \& J. Subagja. 2008. The population and habitat of Tambra fish, Tor tambroides (Bleeker, 1854) in Muller Mountain waters Central Kalimantan. Biodiversitas, 9(4): 306-309. (in Bahasa Indonesia).

Haryono. 2006. Biological aspects of tambra fish (Tor tambroides Blkr.) that exotic \& rare for its domestication. Biodiversitas, 7(2): 195-198. (in Bahasa Indonesia). 
Hinton, D.E. 1990. Histological techniques. In: Schreck, C.B., Moyle, P.B. (Eds.), Methods for Fish Biology. Am. Fish. Soc. Benthesda, Maryland, pp. 191-209.

Jonsson B. \& N. Jonsson. 1993. Partial migration: niche shift versus sexual maturation in fishes. Reviews in Fish Biology and Fisheries, 3,: 348365.

Kiat, Ng Chi. 2004. The Kings of the Rivers Mahseer in Malaysian \& the Region. Selangor: Inter Sea Fishery.

Lucio, P \& A. Uriarte. 1990. Aspects of the reproductive biology of the anchovy, Engraulis encrasicolus L., during 1987 and 1988 in the Bay of Biscay. ICES CM 1990/H: 27, 20 pp.

M. Pollar, M. Jaroensutasinee, and K. Jaroensutasinee. 2007. Morphometric Analysis of Tor tambroides byStepwise Discriminant and Neural Network Analysis. World Academy of Science, Engineering and Technology, 16-20 p.

Morgan, M.J. \& E.B Colbourne. 1999. Variation in maturity-at-age and size in three populations of American plaice. ICES J. Mar. Sci, 56: 673-688.

Motos, L \& A. Uriarte. 1991. An egg production estimate of biomass of the Bay of Biscay anchovy in 1990. ICES CM 1991/ H:32, 24 pp.
Parrish, R.H., D.L. Mallicoate, \& R.A. Klingbeil, 1986. Age dependent fecundity, number of spawning per year sex ratio, and maduration stages in northern anchovy Engraulis mordax. Fish. Bull, 84: 503517.

Stearns, S.C \& J. Koella. 1986. The evolution of phenotypic in lifehistory traits: predictions for norms of reaction for age and size at maturity. Evolution, 40: 893-913.

Stearns, S.C \& R.E. Crandall. 1984. Plasticity for age and size at sexual maturity: a life-history response to unavoidable stress. In: Potts, G.W., Wootton, R.J. (Eds.), Fish Reproduction: Strategies and Tactics. Academic Press, London, pp. 13-33.

Tan, E.S.P. 1980. Some aspects of the biology of malaysian riverine cyprinids. Aquaculture, 20 : 281-289.

Winemiller K. \& K. Rose. 1992. Patterns of life history diversification in North American fishes: implications for population regulation. Canadian Journal of Fisheries and Aquatic Sciences, 49: 2196-2218.

Wootton, R.J., 1998. Ecology of Teleost Fishes, 2nd ed. Kluwer Academic Publishers, London. 